\title{
Empowerment Strategy of Marginal Group for Rusunawa Rawabebek Residents
}

\author{
Retnowati Wahyuning Dyas Tuti ${ }^{1}$, Oneng Nurul Bariyah ${ }^{2}$, Mawar $^{3}$, Dini Gandini $\mathrm{P}^{4}$ \\ \{retnowatiwdtuti@yahoo.com¹, n.oneng@umj.ac.id², mawarhidayat22@gmail.com³, \\ purbaningrum_dg@ymail.com ${ }^{4}$ \} \\ Universitas Muhammadiyah Jakarta, Indonesia ${ }^{1,2,3,4}$
}

\begin{abstract}
This paper describes the empowerment strategy for the marginal community in Rawabebek residents in DKI Jakarta. Research Objectives for: 1). Analyzing the assistance through empowerment given to the relocation of residents in the low-cost housing. 2). Finding Supporting and Inhibiting Factors. The method used is descriptive with. Qualitative Approach. Data collection techniques: Observation, Interview, Documentation and FGD. Informant Withdrawal Techniques: Purposive and Accidental Sampling. Data Analysis: MaccNabb, Data Validity Test: Triangulation. Research Results: The strategy of empowerment use direct action with a group cycle approach through the establishment of a waste bank in each group of residents of Rawabebek Rusunawa. Supporting factors are the strong desire of participants to make changes, especially increasing income. The inhibiting factor is that there are still residents who have not received complete information, not all information has reached all residents, there are still residents who do not understand the importance of a garbage bank.
\end{abstract}

Keywords: Empowerment, Marginal Community, Rusunawa Rawabebek, Jakarta.

\section{Introduction}

Jakarta is the Center of the Republic of Indonesia, so that the DKI Jakarta Regional Government continues to strive to arrange the development of the region in its region in order to provide welfare to the citizens of DKI Jakarta. The structuring of the development was carried out among others by relocating the community to several places. Among the people of DKI Jakarta, they were moved to Rusunawa Rawabebek in Cakung, East Jakarta.

The removal of residents in the Rusunawa occurred in some steps and was motivated by any reasons. In this case, most of them are relocation of riverbanks which are the capital's arrangement areas. Residents who are relocated in general are the economic community down where they have jobs that are very dependent on the location where they live, such as fishermen who live close to the beach. Likewise, the laborers of coolies in the market are dependent on the market. The existence of relocation certainly affects their lives which are different from the situation and conditions when they are in their original place of residence [1].

In addition to the obstacles faced by the residents of relocation in Rusunawa, the problem is also faced by the Management Unit of Rental Flats (UPRS) related to residents called LowIncome Communities/MBR. Moreover, the new Rusunawa building has never been inhabited. 
Problems can arise from residents and buildings and their environment. Among the residents there are also those who have a large house in their original residence, but they must surrender and accept the condition of the narrow flat, only rooms and kitchens measuring 24 square meters.

Another problem faced by residents is the limited mode of transportation. Then, the water in Rawabebek is not good for bathing or drinking, because the occupants feel itching on their skin. The water cannot be cooked, residents must buy gallon water, additional daily living expenses [1].

Based on the data above, residents who have difficulties in developing life and overcoming economic difficulties need to be provided with social assistance through empowerment. This study analyzes the strategy of empowering marginal communities in Rusunawa Rawabebek Jakarta.

\subsection{Formulation of Problem}

Based on the above background, problems are as follows:

a) What is the strategy carried out in an effort to empower residents of Rusunawa Rawabebek of Jakarta?

b) What is the supporting and inhibiting factors in empowering the residents of Rusunawa Rawabebek of Jakarta?

\section{Theory and Concepts}

\subsection{Empowerment}

Empowerment is a concept in an effort to make strength. The word "empowerment" according to the Indonesian dictionary come from the word power means strength, influence, reason, and deception [2]. Empowerment means trying or endeavor in earnest. In English, empowerment is equivalent to the word empowerment. The word empowerment comes from empowerment. The word to empower means to enable, empower, feel and empower. Empowerment theory develops in the United States as a reaction and encouragement from oppressed communities, making them powerless and out of pressure [3].

Community empowerment is an effort to provide empowerment or strengthening to the community. According to Suharto [4] empowerment is interpreted as a process and goal. As a process that empowerment is a series of activities to strengthen weak groups in society, including individuals who experience poverty problems. As a goal, community empowerment aims to achieve the intended situation. Empowerment is related to efforts to change the ability of a person, family, or group from a state of not having the ability/strength/empowerment towards a better state [2].

According to Fahrudin [5] community empowerment is an effort to enable and independence the community in order to achieve three directions, namely:

a) Enabling is creating an atmosphere that allows the community to develop;

b) Empowering, namely increasing capacity by strengthening the potential or power of the community;

c) Protecting, namely protecting the interests by developing a protection system for the community that is the subject of development. 
Community Empowerment Objectives [6]

a) Improvement of institution (better institution);

b) Better business;

c) Better income;

d) Improvement of the environment (better environment);

e) Better living;

f) Better community.

Principles of empowerment, the principles of equality, participation, self-reliance or independence and sustainability [7]. The community empowerment approach is:

a) The lifecycle of human resource development;

b) Life cycle of productive business development;

c) Group institutional life cycle.

There are three strategies for community empowerment, namely: 1) Traditional strategy, which is to suggest that the community knows and chooses the best interests in a variety of circumstances; 2) Direct-action strategy, which is an empowerment strategy in the presence of a dominant party in making decisions; and 3) transformative strategy which is a strategy that shows that mass education in the long term before identifying self-interest [8].

\subsection{Marginal}

Originally the word marginal. If it is said to be marginalizing/it means to marginalize, to discredit KBBI [9]. Marginal Communities are people who live in cities that have a nonpermanent income or have economic limitations. To find out more about marginal communities, we can see the concept of social stratification [10].

\section{Research Methods}

Research approach with descriptive analysis with the New Public Service Theory/New Public Service. Data collection is carried out through observation, interviews, documentary review and focus group discussions. Documentation is done in the library. Informants were chosen purposively, there were 20 people. When data collection is also carried out data analysis using Mac Nab with 6 steps, namely: 1) Organizing Data; 2). Categories, Themes and Patterns; 3). Data Encoding); 4). Application of Ideas, Themes and Categorization; 5). Alternative Search Explanation; and 6). Write and Present a Report. Data Validity Test uses Triangulation.

\section{Results and Discussion}

\subsection{Empowerment Strategy}

The chosen empowerment strategy is an easy method for the residents of the flat. In addition, it can be managed by them and provide income and educate residents to manage 
activities. In this case empowerment of occupants is done through the formation of groupbased waste banks.

The first step is to hold a hearing with the UPRS related to empowerment activities through the establishment of a waste bank. The establishment of a waste bank in Rusunawa Rawabebek as an effort to overcome the economic problems of the residents of the flats that are still unstable after their move to the Rawabebek Flats, which according to the findings of Retno et al [1], caused many residents to be in arrears in rental towers that were increasingly piling up. The garbage bank program is also an effort to socialize a sustainable environment starting from, with the concept of $3 \mathrm{R}$ (reduce, reuse, recycle). After obtaining permission from the UPRS Manager, an FGD was then carried out with the heads of RT, RW and community leaders, to convey the idea of a garbage bank, and a plan to invite community representatives for socialization activities.

Head of RT, RW welcomed the idea of the garbage bank, then a meeting was held with representatives of citizens from each Block in Rusunawa Rawabebek. In this case there were 8 blocks represented by at least 5 people, consisting of: RT Head and superior residents in each each block in the flat. On this occasion they received education from researchers related to the environment, for example about the importance of protecting the environment, current environmental conditions that are already alarming, waste that is not taken care of, etc. Participants who were present were given a pre-test to see the understanding of participants related to the environment. Then proceed with the education of waste banks, related to waste that can be of economic value, the culture of sorting waste at home, classification of waste and others. In the introduction of the waste bank, it was conveyed the understanding of the waste bank, the waste management flow, the profit-sharing system and the positive aspects of the waste bank, so that residents were moved to become members of the waste bank.

Educational activities were followed by technical training related to the garbage bank with the aim of introducing the standardization of the garbage bank system, the working mechanism of the garbage bank, the benefits of the garbage bank. This is done so that residents understand the workflow of the waste bank starting from sorting garbage at home, collecting, depositing, weighing, recording and depositing to collectors. Including the administration required, such as a book of savings, a savings book of customers and others. In this forum residents also held discussions in small groups per block to form the Waste Bank management per Block, named the garbage bank, appointed the Chairman of the Waste Bank, the schedule for depositing waste, the location of the waste bank secretariat, and a follow-up plan carried out by the management of the garbage bank to socialize garbage banks to residents in each block.

Furthermore, at the time agreed upon by the residents and researchers, the researchers distributed large size plastic sacks to all of the towers, totaling 723 sacks and 8 digital scales. Each Trash Bank gets 1 scale, the hope can be the initial capital and enthusiasm for the flats residents to participate in garbage bank. The researcher also conveyed to the residents the monitoring and evaluation plan which will be carried out periodically by researchers and students regarding the implementation of the waste bank in each block.

After 2 (two) weeks of submission and sacks and scales, researchers and several students conducted the first monitoring and evaluation to Rusunawa Rawabebek. The researcher reobserves the socio-economic conditions of the flat residents, as well as interviews related to the operation of the garbage bank in the flat. Lecturers and students are divided into 8 groups according to the number of existing Blocks, Blocks A, B, C, D, Cendrawasih, Merpati, Gelatik and Merak. The results of observations and interviews related to the implementation of the Waste Bank in the first 2 (two) weeks after the delivery of sacks and scales are information 
related to the existence of the Garbage Bank program in each block has been conveyed to each resident of the flat. Information was conveyed by the Head of the RT, the Management of the Waste Bank, or the Management of the Flat Housing, but the form of delivery was still informal, namely by word of mouth, no special socialization had been held from the RT Head or the management regarding the Waste Bank program in Rusunawa Rawabebek.

This is still not in accordance with the Follow Up Plan prepared by the Head of the RT and the Board of Waste Bank during the workshop, previously it was planned that the socialization of the Waste Bank would be carried out by word of mouth, through meetings for outreach, sending information through WhatsApp groups, postings on the wall and others, but for now what has been done is only through word of mouth information. This caused the majority of respondents who were interviewed to say they did not understand the mechanism of the Trash Bank's work. The information that was known was only limited to the current Trash Bank program in Rusunawa.

Understanding of the Waste Bank is still lacking, residents also do not understand the technical implementation of the waste bank, also the mechanism of the Waste Bank system. The mechanism of the related garbage bank system, sorting household garbage from the house, depositing the garbage bank, weighing the waste, recording, and transportation has not been disseminated in detail. Operational meetings with residents have not yet been carried out regarding matters; location of the waste bank, designated collectors, grouping of garbage that can be deposited based on category, type, minimum weight of garbage that can be deposited, deposit schedule, time period for withdrawal of savings. This has caused residents in the first week to be very new to the existing garbage bank program.

Residents have not been active in sorting trash, only a small number have started sorting trash, and even then, only sort plastic waste, because the information conveyed by the Head of RT, and the Management of Waste Bank is still limited. Garbage sacks distributed through the garbage bank management have not been evenly distributed, the Block that most of the residents have received garbage sacks only in Block A, while there are still many sacks of garbage that have not been distributed by the garbage bank management. For Block C, sacks are only given to residents who are interested in participating in the garbage bank program.

However, after being explained in more detail by the research team regarding the benefits of the waste bank, especially related to being able to become additional income for households, most of the residents were enthusiastic, and were interested in joining the waste bank customers, although there were some residents who were also skeptical about the sustainability of the garbage bank. The residents were enthusiastic because based on our research the previous year, some of the residents of Java's Rawa were relocated from the Fish Market and Bukit Duri. Relocation is very influential on their income, many people lose their jobs, the household economy becomes very difficult. It is hoped that with the existence of this Garbage Bank, it can lighten their daily economic burden.

However, the serious concern of the residents is related to the garbage storage in their homes, while waiting for the deposit schedule, because of the small size of the room they feel less spacious to be filled with garbage deposits, and if too long worried about creating odors, and damage health and hygiene. Related to the condition of the existing infrastructure built by residents of Block A complaining about blocked toilets, Block $\mathrm{C}$ wants adequate health facilities in the apartment, Block D bathrooms are often damaged, and often power outages. Residents also hope that the flat environment can be more shade planted with fruit trees and shade trees to be shady. There are still many residents who have not felt at home living in the flat, even though they realize they have no other choice, the pain due to relocation is still very much felt in Rusunawa Rawabebek. 
On September 21, 2019 observations and interviews were conducted again regarding the implementation of the Trash Bank program in Rusunawa Rawabebek. Most of the flats residents in all blocks have gotten garbage bags, many trash bags have also been placed in the corridors in front of the rooms, especially in the Gelatik Block. Residents of the flat have started to sort waste and join into customers of the waste bank, especially for residents in the Merpati Block, Block A and Block D. For other blocks knowledge about the mechanism of the garbage bank is still lacking, including how to sort waste. Information obtained related to operational standards and the mechanism of the garbage bank is still confusing, such as confusion about who collects waste in the Merak Block, there is no certainty the schedule for collecting garbage by collectors occurs in Cendrawasih Block, the certainty of the time of deposit is unclear, occurs in Block A, also the price of waste per kilogram is not yet clear.

However, the process of sorting, collecting, depositing, and weighing the waste began. Residents still hope that socialization will continue and be improved so that the information received can be evenly distributed. So that residents can understand more about the garbage bank and its detailed mechanism, also more and more residents are becoming customers of the Waste Bank. The hope of the garbage bank residents can be sustainable and useful for their economy, and create a cleaner and healthier environment, not vice versa.

\subsection{Supporting and Inhibiting Factors}

Supporting factors in the empowerment program in Rusunawa are the desire of citizens to make changes, especially to increase income so that they can meet their daily needs.

The obstacle faced is the existence of indifference from some residents towards empowerment through the garbage bank. They assess the garbage bank program does not provide great benefits. In addition, the program is a barrier because the garbage bank program has not been socialized to all residents.

\subsection{Analysis of Findings}

The empowerment strategy is carried out with group-based direct action. This is done so that the program's goals are achieved, namely improved income (better income) which will lead to a better life (better living). For this reason, inter-group cooperation is an important force in implementing empowerment programs and solving all problems that become obstacles. 
The empowerment model can be seen in the following figure:

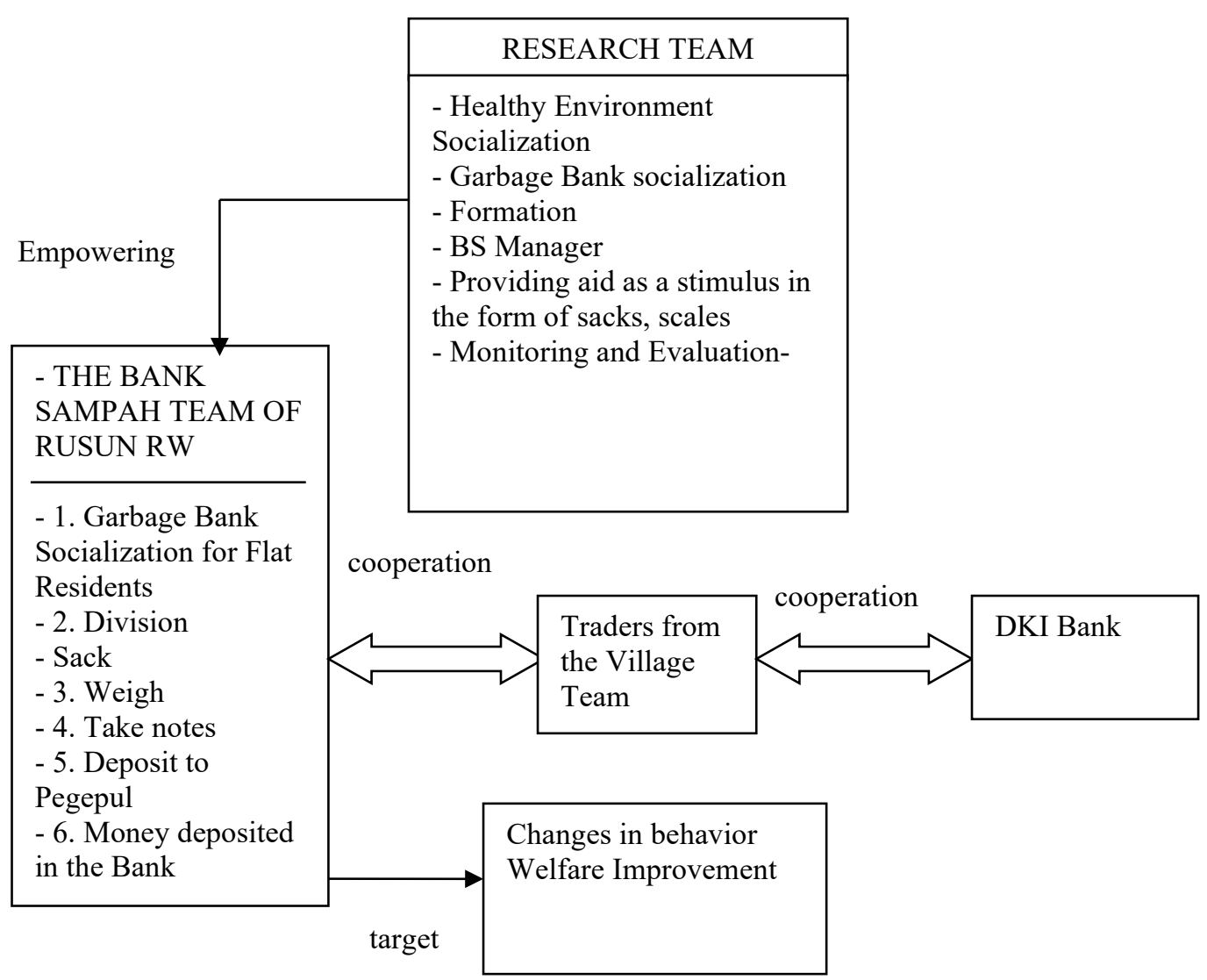

Conversely, the absence of collaboration will complicate the achievement of empowerment program results. For this reason, cooperation between parties must be well established. Good collaboration will make the program sustainable so that the desired results will be realized. Togetherness and cohesiveness among group members is important in achieving the goals of increasing income, better livelihoods and better society.

\section{Conclusion}

Based on the above discussion conclude the following conclusions:

a) Empowerment strategy taken is direct action with a group life cycle approach through the establishment of a waste bank in each group of residents of Rusunawa Rawabebek.

b) Supporting factors are the strong desire of participants to make changes, especially increasing income. 
c) The inhibiting factor is that there are occupants who have not received complete information, not all information has reached all residents, there is still miscommunication between residents.

\section{References}

[1] D. G. P. Tuti, Retno WD.; Bariyah, Oneng Nurul; Mawar, "The Dilemma of Community Relocation in Rusunawa at Jakarta," IJSAE J., vol. 6, no. 11, 2017.

[2] O. N. Bariyah, Total Quality Management of Alms Principles and Practices of Economic Empowerment. Wahana Kardofa FAI UMJ, 2012.

[3] M. Sanrego, Tulizar D.; Taufik, Fiqh Tamkin (Jurisprudence Empowerment) Building Social Capital in Realizing Khiaru Ummah. Jakarta: Qisthi Press, 2016.

[4] E. Suharto, Building Communities Empowering People: Strategic Studies of Social Welfare Development \& Social Work. Bandung: Refika Aditama, 2017.

[5] A. Fahrudin, Empowerment, Participation and Capacity Building. Bandung: Humanities, 2012.

[6] T. Mardikanto, CSR (Corporate Social Responsibility) Corporate Responsibility. Bandung: Alfabeta, 2014.

[7] Najiati, Community Empowerment on Peatlands. Bogor: Wetlands International, 2005.

[8] H. Hikmat, "Community empowerment strategy," Hum. Utama, Bandung, 2006.

[9] D. P. Nasional, "Kamus Besar Bahasa Indonesia (KBBI)," Jakarta: Gramedia, 2008.

[10] R. Djaffar and H. Cangara, "Internet dan Masyarakat Marginal di Kota Makassar; Studi Kasus Pemanfaatan Galeri Internet Bbppki," KAREBA J. Ilmu Komun., vol. 1, no. 4, pp. 361-371, 2016. 